\title{
Environmental stresses inhibit splicing in the aquatic fungus Blastocladiella emersonii Raphaela Castro Georg ${ }^{1,2}$, Rosane MP Stefani ${ }^{1}$ and Suely Lopes Gomes*1
}

Address: ${ }^{1}$ Departamento de Bioquímica, Instituto de Química, Universidade de São Paulo, Brazil and ${ }^{2}$ Departamento de Bioquímica e Biologia Molecular, Instituto de Ciências Biológicas, Universidade Federal de Goiás, Brazil

Email: Raphaela Castro Georg - raphaela@iq.usp.br; Rosane MP Stefani - rosanestefani@yahoo.com.br; Suely Lopes Gomes* - sulgomes@iq.usp.br

* Corresponding author

Published: 29 October 2009

BMC Microbiology 2009, 9:231 doi:10.1|86/|47|-2|80-9-23|
Received: 10 February 2009

Accepted: 29 October 2009

This article is available from: http://www.biomedcentral.com/|47|-2/80/9/23।

(C) 2009 Georg et al; licensee BioMed Central Ltd.

This is an Open Access article distributed under the terms of the Creative Commons Attribution License (http://creativecommons.org/licenses/by/2.0), which permits unrestricted use, distribution, and reproduction in any medium, provided the original work is properly cited.

\begin{abstract}
Background: Exposure of cells to environmental stress conditions can lead to the interruption of several intracellular processes, in particular those performed by macromolecular complexes such as the spliceosome.

Results: During nucleotide sequencing of cDNA libraries constructed using RNA isolated from $B$. emersonii cells submitted to heat shock and cadmium stress, a large number of ESTs with retained introns was observed. Among the 6,350 ESTs obtained through sequencing of stress cDNA libraries, 18 I ESTs presented putative introns (2.9\%), while sequencing of cDNA libraries from unstressed $B$. emersonii cells revealed only $0.2 \%$ of ESTs containing introns. These data indicate an enrichment of ESTs with introns in B. emersonii stress CDNA libraries. Among the 85 genes corresponding to the ESTs that retained introns, 19 showed more than one intron and three showed three introns, with intron length ranging from 55 to 333 nucleotides. Canonical splicing junctions were observed in most of these introns, junction sequences being very similar to those found in introns from genes previously characterized in B. emersonii, suggesting that inhibition of splicing during stress is apparently a random process. Confirming our observations, analyses of $g p \times 3$ and hsp 70 mRNAs by Northern blot and SI protection assays revealed a strong inhibition of intron splicing in cells submitted to cadmium stress.
\end{abstract}

Conclusion: In conclusion, data indicate that environmental stresses, particularly cadmium treatment, inhibit intron processing in B. emersonii, revealing a new adaptive response to cellular exposure to this heavy metal.

\section{Background}

Exposure to environmental stresses leads to the disruption of many intracellular processes, in particular those carried out by macromolecular complexes, which are extremely sensitive to perturbation by stress conditions [1]. An example of a macromolecular complex that could be affected by environmental stresses is the spliceosome, which is responsible for intron excision, an important cellular process. The spliceosome is a multicomponent complex formed by hundreds of proteins and five small nuclear RNAs (U1, U2, U4, U5 and U6 snRNAs) assembled on the newly synthesized precursor messenger RNA (pre-mRNA) [2,3]. This complex catalyzes a two-step transesterification reaction required to remove the introns 
and connect the exons $[4,5]$. Intron splicing is a precisely regulated process, where only four intron sequences guide spliceosome machinery. They are: the exon-intron junction at the 5' and 3' end of the introns (5'ss - GT, 3'ss $\mathrm{AG}$ ); the branch site sequence located upstream of the 3 'ss; and the polypyrimidine tract located between the 3'ss and the branch site [6].

The aquatic fungus Blastocladiella emersonii belongs to the Chytridiomycete class, which is at the base of the fungal phylogenetic tree $[7,8]$. Throughout its life cycle this fungus suffers dramatic biochemical and morphological changes, especially during two distinct stages of cell differentiation: germination and sporulation [9]. Both stages can be induced with a high degree of synchrony, and drastic changes in the patterns of RNA and protein syntheses are observed throughout the fungus life cycle. In nature, $B$. emersonii can be exposed to distinct environmental conditions, as temperature fluctuations and presence of heavy metals, as cadmium, that could lead to the disruption of some cellular functions.

It was previously shown that the splicing machinery is sensitive to thermal stress, as exposure of Saccharomyces cerevisiae cells to heat shock at $42^{\circ} \mathrm{C}$ leads to the accumulation of pre-mRNA species containing unspliced introns [10]. This splicing inhibition was also observed in a variety of species from yeast to humans, including B. emersonii [10-14]. However, the splicing machinery seems to be more thermoresistant in $B$. emersonii because at the lethal temperature of $42^{\circ} \mathrm{C}$, when cell viability falls to less than $1 \%$ and protein synthesis is decreased by more than $95 \%$ [15], splicing is only partially inhibited in this fungus (30\% inhibition) [13]. In yeast and Drosophila melanogaster at extreme temperatures splicing is inhibited more than $70 \%[10,11]$.

Although the effects of heat shock in the splicing machinery have been known for more than two decades [11], there is little information in the literature about how cadmium affects this complex. Cadmium $\left(\mathrm{Cd}^{2+}\right)$ is a divalent cation present in polluted environments, which causes oxidative stress, lipid peroxidation and mutagenesis in the cells $[16,17]$. However, the molecular mechanisms by which cadmium leads to reactive oxygen species production and oxidative stress are largely unknown and are probably indirect. The mechanism usually proposed for cadmium toxicity is its binding to cellular proteins, resulting in the inhibition of some essential enzymes. As cadmium has high affinity for thiol groups, it is thought to bind accessible cysteine residues in proteins [16]. Another possible effect of cadmium exposure is the displacement of zinc and calcium from metalloproteins, leading to inhibition of these important proteins [16-18]. In this way, the presence of cadmium in the cells could affect, in the- ory, any biological process including the spliceosome machinery.

In this study, we demonstrate that environmental stresses, in particular, cadmium treatment inhibits splicing in the aquatic fungus $B$. emersonii. This inhibition is dosedependent since we observed more unspliced mRNAs when higher cadmium concentrations were used. Thus, this work shows a new deleterious effect in RNA processing machinery when cells are exposed to cadmium.

\section{Methods}

\section{Construction of cDNA libraries from stressed cells}

ESTs analyzed in this work were obtained through the sequencing of three different cDNA libraries constructed from cells of $B$. emersonii submitted to heat shock and cadmium stress. The description of RNA extraction, cDNA library construction and EST sequencing is shown in [19]. Briefly, cDNA libraries were constructed from RNA samples isolated from sporulating cells exposed to heat shock at $38^{\circ} \mathrm{C}$ from 30 to $60 \mathrm{~min}$ after starvation (HSR library) or to $50 \mu \mathrm{M} \mathrm{CdCl}_{2}$ during the same period (CDM library) and from sporulating cells exposed to $100 \mu \mathrm{M} \mathrm{CdCl}_{2}$ from 60 to 90 min after starvation (CDC library).

\section{Identification of putative introns in B. emersonii ESTs}

To identify putative introns, all ESTs obtained from the sequencing of the HSR, CDM and CDC CDNA libraries were grouped using Cap3 program [20]. The unigenes obtained (contigs plus singlets) (BeSAS - B. emersonii Stress Assembled Sequences) were compared with B. emersonii EST databank (BeAS - B. emersonii Assembled Sequences) using BlastN tool [21]. BeAS databank was generated from the sequencing of cDNA libraries constructed using RNA samples obtained from cells at different $B$. emersonii life cycle stages and that were not submitted to stress conditions $[22,23]$. BeSAS unigenes that presented extended regions of nucleotide identity with BeAS unigenes separated by regions that do not presented any nucleotide identity were pre-selected to be analyzed. We performed a search for canonical splicing junctions in these pre-selected BeSAS unigenes as well as for sequences corresponding to the putative branch site.

\section{Identification of putative genes encoding mRNA processing proteins in B. emersonii}

We grouped all ESTs sequenced in B. emersonii transcriptome project (ESTs from stress and non-stress cDNA libraries) by using Cap3 program (BeSCAS - B. emersonii Stress and Cycle Assembled Sequences) and annotated the putative genes according to Gene Ontology (GO) terms. For more details, see references [19,23]. All BeSCAS genes that were annotated to the GO term "mRNA processing" (GO:0006397) were selected to be manually analyzed. 


\section{Northern blot analysis}

Total RNA was isolated from synchronized B. emersonii cells during sporulation, maintained at their physiological temperature $\left(27^{\circ} \mathrm{C}\right)$ or exposed to heat shock $\left(38^{\circ} \mathrm{C}\right.$ during $30 \mathrm{~min})$ and cadmium $\left(50 \mu \mathrm{M} \mathrm{CdCl}_{2}\right.$ and $100 \mu \mathrm{M}$ $\mathrm{CdCl}_{2}$ during $30 \mathrm{~min}$ ) using TRIzol reagent (Invitrogen) according to manufacturer's instructions. Gel electrophoresis and blotting were performed as described in [24].

\section{SI protection assays of hsp70-I RNA}

The 5' end-labeled probe was prepared by labeling an 18nt primer with $\left[\gamma_{-32}{ }^{32}\right]$ ATP and T4 polynucleotide kinase, which was then annealed to a single-stranded DNA from M13mpl8 containing a $2.3 \mathrm{~kb}$ BamHl-Sacl fragment of hsp70-1 genomic clone (coding strand) [13], and extended using the Pollk. The extending reaction was carried out in $12.5 \mathrm{mM}$ Tris- $\mathrm{HCl}$ buffer $\mathrm{pH} 8.0$ containing $6.25 \mathrm{mM} \mathrm{MgC1}_{2} / 25 \mu \mathrm{M}$ dATP, dCTP, dTTP and dGTP and 5 units of Pollk. After incubation for $15 \mathrm{~min}$ at room temperature the enzyme was inactivated at $65^{\circ} \mathrm{C}$ for $10 \mathrm{~min}$. The probe $\left(4 \times 10^{5} \mathrm{cpm}\right)$ was ethanol precipitated with 50 $\mu \mathrm{g}$ of total RNA isolated from cells at different stages of the life cycle and from cells submitted to different concentrations of $\mathrm{CdCl}_{2}$. The pellet was then suspended in $28 \mu \mathrm{l}$ of formamide and $7 \mu \mathrm{l}$ of $40 \mathrm{mM}$ Pipes buffer, $\mathrm{pH}$ 6.4, containing $400 \mathrm{mM} \mathrm{NaC1/1} \mathrm{mM} \mathrm{EDTA.} \mathrm{After} \mathrm{boiling} \mathrm{the}$ samples for $10 \mathrm{~min}$, the annealing was carried out for $3 \mathrm{~h}$ at $52^{\circ} \mathrm{C}$. The samples were then diluted with $350 \mu \mathrm{l}$ of 30 $\mathrm{mM}$ Na-acetate buffer $\mathrm{pH} 4.6 / 250 \mathrm{mM} \mathrm{NaCl} / 1 \mathrm{mM}$ $\mathrm{ZnSO}_{4} / 20 \mu \mathrm{g}$ per $\mathrm{ml}$ calf thymus DNA, and digested at $37^{\circ} \mathrm{C}$ for $30 \mathrm{~min}$ with 50 units of S1 nuclease (GE Healthcare). The nucleic acids were ethanol precipitated, suspended in $4 \mu \mathrm{l}$ of formamide sample buffer, and analyzed in $7 \mathrm{M}$ urea-6\% PAGE followed by autoradiography. The fragments were sized by comparison with Mspl digest ${ }^{32} \mathrm{P}$ labeled pBR322 DNA.

\section{Results}

\section{B. emersonii stress cDNA libraries are enriched in ESTs with introns}

The sequencing of ESTs from cDNA libraries constructed from B. emersonii cells submitted to heat shock and cadmium stress suggested that introns have been retained in several of them. Therefore, we speculated that the stress conditions used to construct these libraries could be affecting mRNA splicing in B. emersonii. To test this hypothesis, we initially identified all the ESTs sequenced from stress cDNA libraries that contained putative introns (iESTs).

Among the 6,350 ESTs sequenced from the stress libraries, 181 ESTs (corresponding to 105 introns retained from 85 distinct genes - Additional file 1) presented putative introns $(2.9 \%)$, while in the sequencing of cDNA libraries from cells not submitted to stresses it was verified that only $0.2 \%$ of the ESTs contained putative introns (Table 1 ). These data are consistent with our hypothesis and indicate that there is an enrichment of ESTs with introns in $B$. emersonii stress cDNA libraries. Interestingly, if we consider the cDNA libraries separately, we observe a more pronounced enrichment of iESTs $(4.9 \%)$ in the cDNA library constructed from cells submitted to the higher concentration of cadmium $(100 \mu \mathrm{M})$ (Table 1$)$.

Among the 85 genes corresponding to the ESTs that retained introns, 19 showed more than one intron and three showed three introns. The intron length ranged from 55 to 333 nucleotides (Figure 1), most of the introns being between 60-79 nt long. To further characterize these putative introns we performed a search for the canonical splicing sites in the regions adjacent to intron sequences and also for the conserved sequence of the putative branch site, which is involved in lariat formation and intron splicing [25]. We detected the conserved dinucleotides at each end of the introns (GT at the 5 ' end and AG at the 3 ' end) in 102 of the 105 putative introns (Figure 2A, Additional file 1). All introns analyzed also presented a sequence similar to the conserved sequence (CTAAC) of the branch site. We performed the same search for the putative introns detected in ESTs from non-stress cDNA libraries and the result was very similar (Figure 2B). In addition, all nine previously characterized genes of $B$. emersonii containing introns showed the canonical splicing sites and a conserved branch site sequence [13,26-33].

These data show that canonical splicing junctions observed in most of the iESTs obtained through the sequencing of stress libraries are not different from other splicing junctions present in introns of genes previously

Table I: Number of iESTs sequenced from stress cDNA libraries.

\begin{tabular}{lccc}
\hline cDNA library & Total of ESTs with introns & Total of ESTs sequenced & Ratio (\%) \\
\hline HSR (Heat shock) & 34 & 3,070 & 1.1 \\
$\mathrm{CDM}\left(\mathrm{CdCl}_{2} 5 \mu \mu \mathrm{M}\right)$ & 65 & 2,400 & 2.7 \\
$\mathrm{CDC}(\mathrm{CdCl} \mid 00 \mu \mathrm{M})$ & 83 & 1,920 & 4.3 \\
Total (stress) & $\mathbf{1 8 I}$ & $\mathbf{6 , 3 5 0}$ & $\mathbf{2 . 9}$ \\
Total (normal) & $\mathbf{4 5}$ & $\mathbf{2 3 , 3 5 0}$ & $\mathbf{0 . 2}$
\end{tabular}

iESTs corresponds to ESTs with retained introns; normal corresponds to cDNA libraries from unstressed cells. 


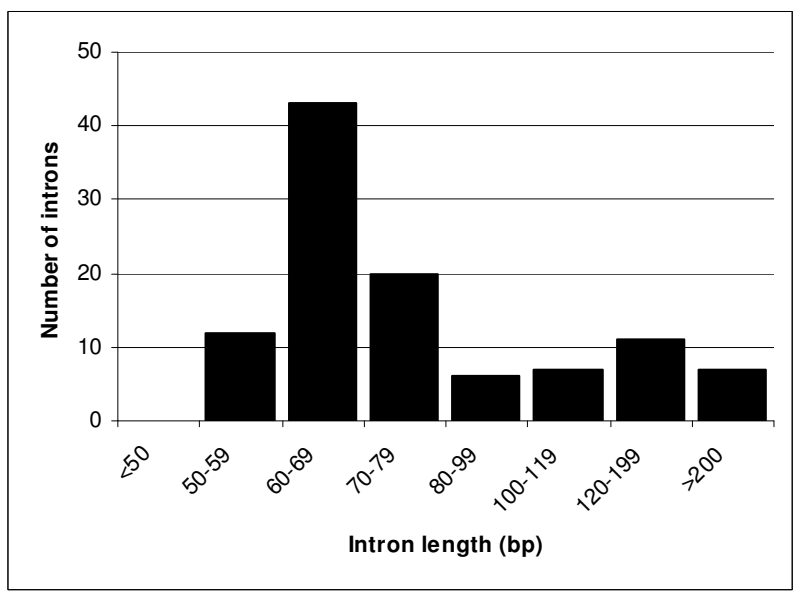

Figure I

Length distribution of 105 B. emersonii introns in ESTs from stress libraries.

characterized in B. emersonii, and also not different from introns retained in ESTs from non-stress libraries. This suggests that the mRNAs that had their splicing inhibited by stress were probably randomly affected or at least if there is a selection for some mRNAs, it is not based in differences in their splicing sites.
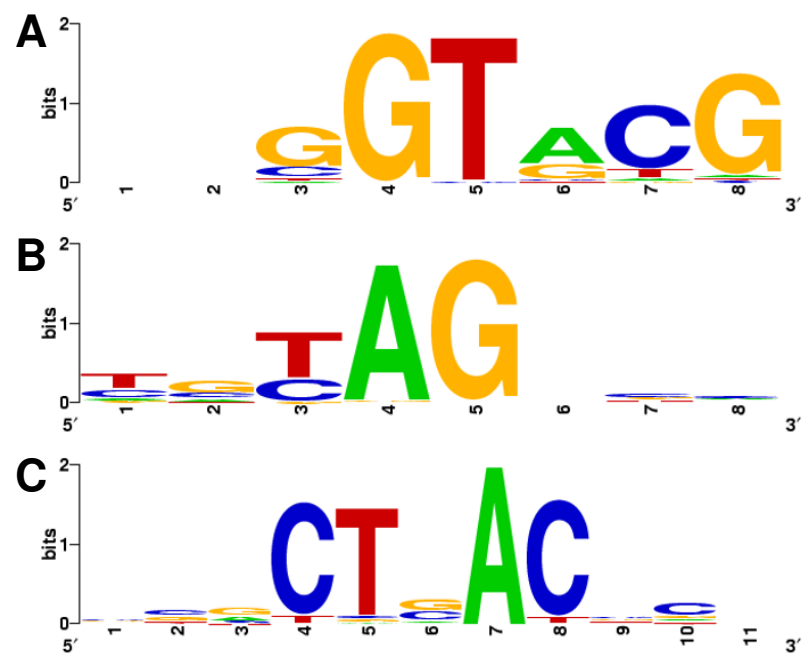

If we consider that selective inhibition of splicing could be a post-transcriptional regulatory mechanism to respond to stressful conditions, we would expect that a group of genes should have their mRNA processing inhibited to enhance the mRNA processing of other genes that could be more important for the response of $B$. emersonii to stress. However, when we analyzed the genes corresponding to the ESTs with introns retained, we did not observe a pattern among them (Additional file 1). On the contrary, some important genes as those encoding HSPs (Heat Shock Proteins), Glutathione-S-transferases and Thioredoxins that are induced in response to stress conditions [19], also presented iESTs sequenced from stress cDNA libraries.

Further evidence that is consistent with this idea is the fact that for $30 \%$ of the iESTs, at least one EST sequenced from stress libraries corresponding to the same gene did not retain the intronic sequences, i.e., the corresponding mRNA was correctly processed (Additional file 1).

\section{The spliceosome genes are not repressed under heat shock and cadmium stress}

The inhibition of mRNA splicing caused by heat shock and cadmium treatment could be due to a decrease in the expression of genes encoding proteins of the spliceosome complex, leading to a reduction in the levels of the proteins forming the spliceosome. To test this hypothesis we
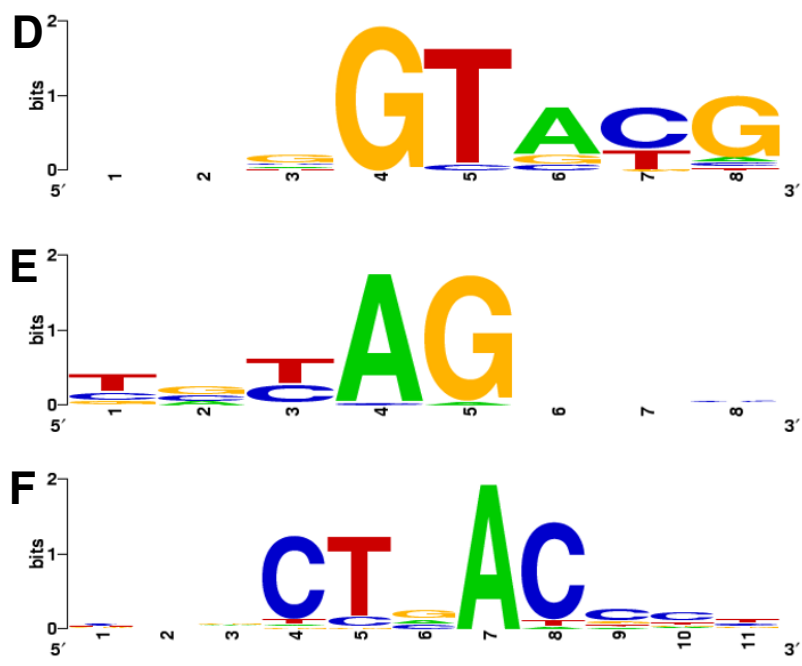

Figure 2

Sequence conservation in B. emersonii introns. Consensus sequences for (A) 5 ' exon-intron junctions, (B) 3' intron-exon junctions and $(C)$ putative branch point sequences were calculated based on 105 introns from ESTs obtained through sequencing of stress cDNA libraries using WebLogo server http://weblogo.berkeley.edu. The consensus sequences for (D) 5 ' exonintron junctions, (E) 3' intron-exon junctions and (F) putative branch point from ESTs obtained through sequencing of nonstress cDNA libraries are also shown. In this case, the consensus sequences were calculated based on 35 introns. The intron sequences start at position four in (A) and (D), and end at position 5 in $(B)$ and $(E)$. 
identified all genes coding for spliceosome proteins that were present in B. emersonii EST database $[19,22,23]$. We observed 41 distinct genes (corresponding to 91 ESTs) encoding proteins involved in mRNA processing in this fungus (Additional file 2). To verify if these genes were upor down-regulated during stress, we used the expression profile data of microarray assays of $B$. emersonii cells submitted to cadmium and heat shock, previously published by our group [19]. Among the 41 genes of B. emersonii related to mRNA processing, 29 were present on the microarray slide and only two of them were shown to be differentially expressed in response to cadmium or heat shock. One was induced by heat shock (BeE60H22E01 snRNP core protein SMX5d) and the other (BeE60N15H01 - putative small nuclear ribonucleoprotein Sm-D1) was repressed by cadmium treatment $[19,23]$.

The 41 genes observed through our search certainly do not correspond to all genes involved in mRNA processing in B. emersonii, since it has been shown that the spliceosome machinery is formed by hundreds of proteins in eukaryotes [2]. However, we believe that our set of genes is a significant part of those that encode proteins of the mRNA processing complex in $B$. emersonii. Nevertheless, we observed that only one gene was repressed under stress conditions. Thus, our data suggest that inhibition of mRNA splicing after cadmium and heat stress in this fungus is not due to a global repression of the genes involved in the splicing process under these conditions.

One of the possible effects of cadmium that lead to toxicity in cells is its capacity of displace zinc $\left(\mathrm{Zn}^{2+}\right)$ and calcium $\left(\mathrm{Ca}^{2+}\right)$ from proteins that need these cations to perform their functions $[16,34,35]$. So, the inhibition of splicing by cadmium in $B$. emersonii could be due to the substitution of zinc in proteins involved in mRNA processing, which could lead to impairment or even to loss of their function. Considering this hypothesis, we evaluated if among $B$. emersonii spliceosome proteins there were some that possessed zinc-binding domains, as zinc finger or zinc-related motifs, which could be affected by the presence of cadmium inside the cells.

Comparing the deduced amino acid sequences from the 41 mRNA processing-related genes from $B$. emersonii with a protein family database (PFAM) [36], we observed two proteins with putative zinc-related domains. They encode the cleavage and polyadenylation specificity factor 5 (BeCSAS2344) and the pre-mRNA splicing factor Cwc2 (BeE30N19E11) [22]. The former protein has a THAP domain, a putative DNA-binding domain that probably also binds a zinc ion, and the second protein has a zincfinger domain. The presence of proteins that possess zincrelated domains has also been reported in the spliceo- some of other organisms [37-40], indicating that this type of protein is a common component of the splicing machinery and could be the target of zinc displacement by cadmium.

\section{Splicing of hsp70-I intron is inhibited by cadmium treatment but not by hydrogen peroxide}

Previous studies showed that the processing of B. emersonii hsp70-1 intron is partially inhibited (30\%) after heat treatment of the cells at the lethal temperature of $42^{\circ} \mathrm{C}$ [13]. The hsp70-1 gene was one of the genes that presented an iEST sequenced from libraries from cells exposed to cadmium stress (Additional file 1). However, we detected no hsp70-1 iEST in the heat shock cDNA library (HSR). This is probably due to the fact that in the construction of the heat shock cDNA library fungal cells were incubated at $38^{\circ} \mathrm{C}$ instead of the restrictive temperature of $42^{\circ} \mathrm{C}$. To confirm the inhibition of $B$. emersonii hsp $70-1$ intron splicing by cadmium treatment, we performed S1 nuclease protection assays using a 5 'end-labeled probe prepared as described in Materials and Methods. The probe was hybridized to total RNA isolated from cells submitted to cadmium treatment $(250 \mu \mathrm{M})$. As a control of splicing inhibition, we also used total RNA isolated from cells submitted to heat shock at $38^{\circ} \mathrm{C}$ and $42^{\circ} \mathrm{C}$.

As depicted in Figure 3, a partial block in $h s p 70-1$ intron splicing occurs after cadmium treatment suggesting that the presence of this heavy metal in cells impairs spliceosome function. The hsp70-1 intron was efficiently processed at $38^{\circ} \mathrm{C}$ but its splicing was partially inhibited when B. emersonii cells were incubated at $42^{\circ} \mathrm{C}$, as previously shown by Stefani and Gomes [13] (Figure 3). To further test if the effect of cadmium on mRNA processing could be due to oxidative stress caused by the presence of the metal in the cells, we also analyzed the effect of hydrogen peroxide treatment on B. emersonii hsp70-1 intron splicing. We did not detect any inhibition of hsp70-1 intron processing when we performed the $\mathrm{S} 1$ nuclease protection assays using total RNA isolated from cells exposed to 0.5 $\mathrm{mM}$ hydrogen peroxide (Figure 3 ). These results suggest that splicing inhibition by cadmium treatment of B. emersonii cells is probably not due to oxidative stress caused by this heavy metal.

As S1 nuclease protection assays were performed using total RNA isolated from cells submitted to a higher concentration of cadmium $(250 \mu \mathrm{M})$ than those used in the construction of the stress libraries $(50$ and $100 \mu \mathrm{M})$, we also performed these assays with RNA isolated from cells submitted to 25,50 and $100 \mu \mathrm{M} \mathrm{CdCl}_{2}$ to verify the effect of different cadmium concentrations on $h s p 70-1$ intron splicing. We observed a more pronounced block in the processing of hsp70-1 intron when $B$. emersonii cells were treated with $100 \mu \mathrm{M} \mathrm{CdCl}_{2}$ than with $50 \mu \mathrm{M} \mathrm{CdCl}_{2}$, while 

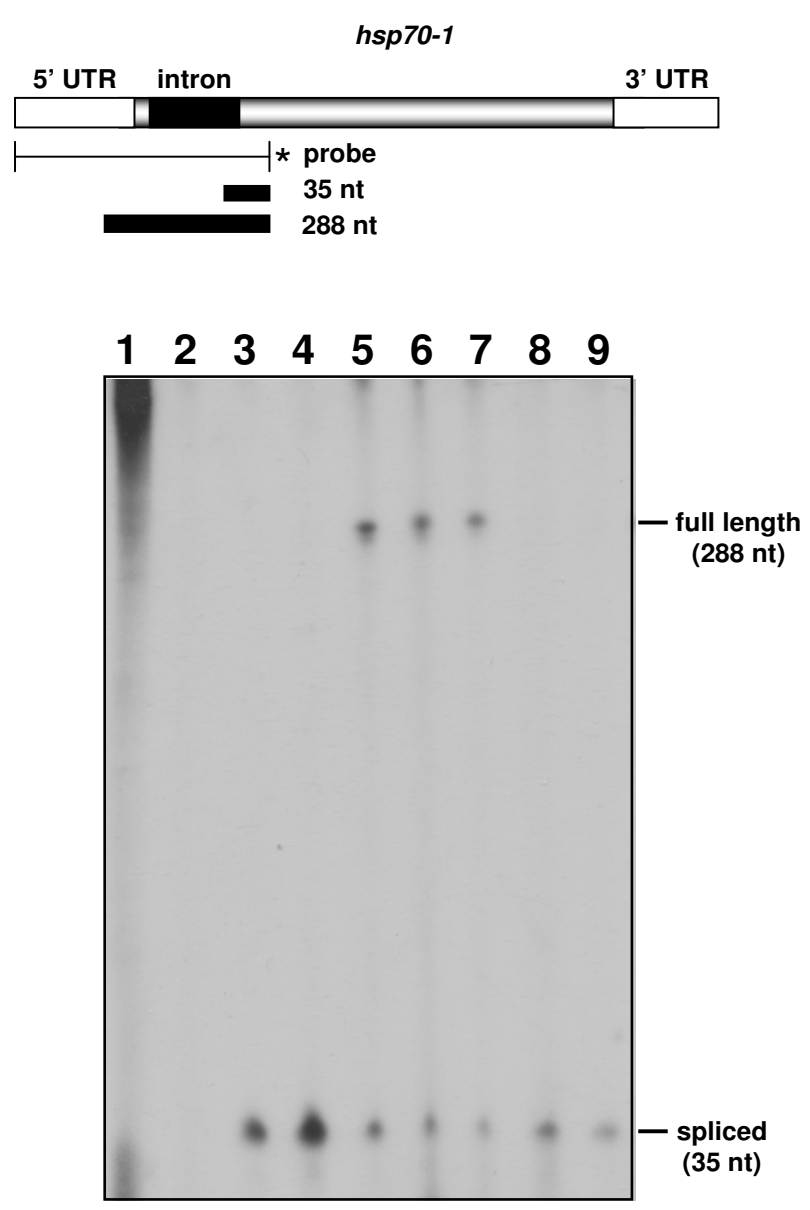

Figure 3

Splicing of hsp70 mRNA is inhibited in B. emersonii cells exposed to cadmium. Nuclease $\mathrm{SI}$ protection assays were performed using the $5^{\prime}$ end-labeled probe, depicted above the autoradiogram, and $50 \mu \mathrm{g}$ of yeast tRNA in the presence or absence of nuclease SI (lanes I and 2) as control, $50 \mu \mathrm{g}$ of total RNA isolated from $60 \mathrm{~min}$ sporulating cells (lane 3), cells submitted to heat shock at $38^{\circ} \mathrm{C}$ and $42^{\circ} \mathrm{C}$ for 30 min (lanes 4 and 5 , respectively), cells submitted to $250 \mu \mathrm{M} \mathrm{CdCl}$ for $30 \mathrm{~min}$ and $60 \mathrm{~min}$ (lanes 6 and 7, respectively), cells submitted to $500 \mu \mathrm{M} \mathrm{H}_{2} \mathrm{O}_{2}$ for $30 \mathrm{~min}$ and 60 $\min$ (lanes 8 and 9 , respectively).

with $25 \mu \mathrm{M} \mathrm{CdCl}_{2}$ no inhibition of splicing was detected (Additional file 3). These results indicate that inhibition of splicing by cadmium treatment can be dose-dependent, consistent with our observation that a larger number of iESTs is found in the cDNA library constructed from cells submitted to $100 \mu \mathrm{M} \mathrm{CdCl}_{2}$ (CDC) than from cells exposed to $50 \mu \mathrm{M} \mathrm{CdCl}_{2}$ (CDM) (Additional file 1).

\section{Induction of thermotolerance by incubation at moderate temperatures restores splicing}

To test whether a pretreatment at moderate heat shock temperatures could exert some effect on mRNA processing in B. emersonii cells, S1 nuclease protection assays were performed using RNA samples from cells incubated at $38^{\circ} \mathrm{C}$ for 30 min prior to exposure to extreme heat shock temperature $\left(42^{\circ} \mathrm{C}\right)$ or cadmium treatment. In these experiments, it was possible to observe that splicing inhibition occurring at $42^{\circ} \mathrm{C}$ could be completely reversed if pre-incubation at $38^{\circ} \mathrm{C}$ was associated with incubation at $27^{\circ} \mathrm{C}$ for $30 \mathrm{~min}$ after exposure to the extreme heat shock temperature (Figure 4A), which could be considered a recovery period. Furthermore, protein synthesis was necessary during the entire experiment, as addition of cycloheximide $(10 \mu \mathrm{g} / \mathrm{ml})$ at any time during cell incubation at the various temperatures prevented complete recovery of the cells' capacity to carry out splicing of hsp70-1 intron (not shown). In particular, addition of cycloheximide before the pre-incubation step at $38^{\circ} \mathrm{C}$, revealed that this treatment is essential for reversing splicing inhibition, as no spliced mRNA is detected under this condition (not shown). In the case of splicing inhibition due to exposure to cadmium, pre-incubation at $38^{\circ} \mathrm{C}$ prior to heavy metal treatment was also capable of reversing inhibition (Figure 4B), but complete recovery of the splicing capacity was observed only if exposure to cadmium was followed by incubation at $27^{\circ} \mathrm{C}$ in the absence of the metal (Figure 4B).

\section{Processing of gpx3 intron is inhibited by cadmium treatment}

To further verify the splicing inhibition by cadmium and its dose-dependent effect, we selected another gene to evaluate intron processing. The gpx3 gene encodes a Glutathione peroxidase and was chosen because its intron is 334-nt length, so unspliced mRNA could be easily differentiated from spliced mRNA in the Northern blot assays. The experiment was carried out using total RNA from $B$. emersonii cells submitted to heat shock $\left(38^{\circ} \mathrm{C}\right)$, and cadmium (50 and $100 \mu \mathrm{M} \mathrm{CdCl}_{2}$ ). The unspliced form of gpx3 mRNA was detected only when cells were treated with cadmium, indicating a partial block in mRNA splicing (Figure 5). Inhibition of splicing was confirmed to be dose-dependent as a more pronounced inhibition was observed when $B$. emersonii cells were treated with the highest concentration of cadmium $(100 \mu \mathrm{M})$. The unspliced form of $g p x 3$ mRNA was not detected when cells were submitted to heat shock at $38^{\circ} \mathrm{C}$, indicating that heat stress at this temperature produces no visible effect in $g p x 3$ mRNA splicing. Interestingly, we observed that the gpx3 gene is induced both in response to cadmium and heat shock, an indication that this gene probably plays an important role in the response of $B$. emersonii to these two environmental stresses. 
A

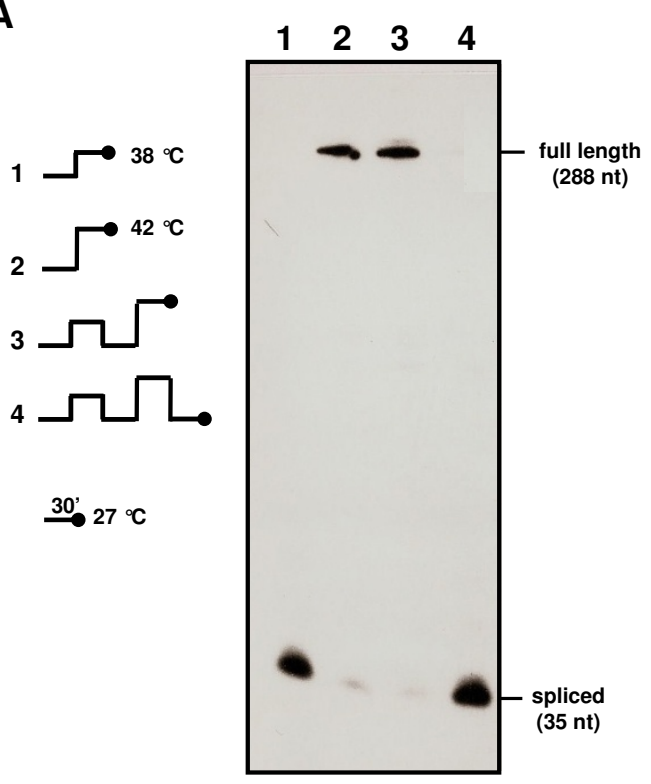

B

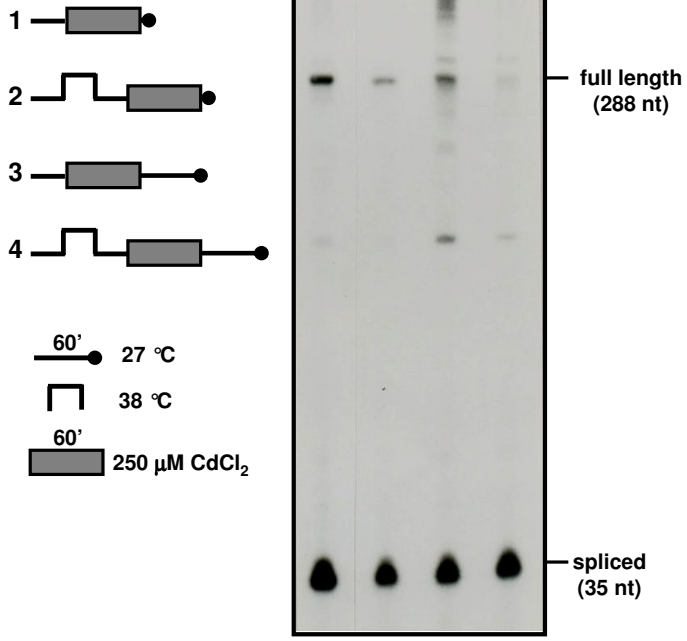

\section{Figure 4}

Effect of thermotolerance on hsp70 mRNA splicing inhibition. A -- Nuclease SI protection assays were performed using a $5^{\prime}$ end-labeled probe (the same used in Figure 3) and $50 \mu \mathrm{g}$ of total RNA isolated from cells incubated at the following temperatures for $30 \mathrm{~min}: 27^{\circ} \mathrm{C}$ and $38^{\circ} \mathrm{C}$ (lane I); $27^{\circ} \mathrm{C}$ and $42^{\circ} \mathrm{C}$ (lane 2); $27^{\circ} \mathrm{C}, 38^{\circ} \mathrm{C}, 27^{\circ} \mathrm{C}$ and $42^{\circ} \mathrm{C}$ (lane 3); $27^{\circ} \mathrm{C}, 38^{\circ} \mathrm{C}$, $27^{\circ} \mathrm{C}, 42^{\circ} \mathrm{C}$ and $27^{\circ} \mathrm{C}$ (lane 4). B -- Cells incubated at $27^{\circ} \mathrm{C}$ for $30 \mathrm{~min}$ and then with $250 \mu \mathrm{M} \mathrm{CdCl}_{2}$ for 60 min (lane I); cells incubated at $27^{\circ} \mathrm{C}$ for $30 \mathrm{~min}$, at $38^{\circ} \mathrm{C}$ for $30 \mathrm{~min}$, at $27^{\circ} \mathrm{C}$ for $30 \mathrm{~min}$, and then with $250 \mu \mathrm{M} \mathrm{CdCl}_{2}$ for $60 \mathrm{~min}$ (lane 2); cells incubated at $27^{\circ} \mathrm{C}$ for $30 \mathrm{~min}$, with $250 \mu \mathrm{M} \mathrm{CdCl}_{2}$ for $60 \mathrm{~min}$ and then at $27^{\circ} \mathrm{C}$ for $60 \mathrm{~min}$ (lane 3); cells incubated at $27^{\circ} \mathrm{C}$ for $30 \mathrm{~min}$, at $38^{\circ} \mathrm{C}$ for $30 \mathrm{~min}$, at $27^{\circ} \mathrm{C}$ for $30 \mathrm{~min}$, with $250 \mu \mathrm{M} \mathrm{CdCl}_{2}$ for $60 \mathrm{~min}$ and then at $27^{\circ} \mathrm{C}$ for $60 \mathrm{~min}$ (lane 4).

\section{Discussion}

A constant challenge for unicellular organisms in nature is to maintain internal homeostasis despite abrupt and dramatic fluctuations in the external conditions. Sudden changes in the external environment can perturb the internal system of the cells, disrupting cellular functions. How organisms respond to these environmental changes to adapt to their surroundings and avoid cellular damages has been the subject of various research groups $[19,41$ 44]. Nevertheless, most of those studies evaluated the effects of these environmental oscillations on gene expression, protein synthesis and cell phenotype [19,41-44], with only a few reporting the effects of stresses on the mechanism of pre-mRNA splicing $[1,45]$.

This work describes for the first time, to the best of our knowledge, inhibition of splicing in vivo as an effect of cadmium treatment. The first evidence indicating this new effect of cadmium in B. emersonii cells was the observation of an enrichment of iESTs in the sequencing of the stress cDNA libraries. From 6,350 ESTs obtained through the sequencing of stress libraries, $2.9 \%$ correspond to iESTs, while in the sequencing of $B$. emersonii cDNA libraries, not submitted to environmental stresses, the percentage of iESTs was only $0.2 \%$.

Two cDNA libraries were constructed from cells submitted to different cadmium concentrations and we observed that the higher the cadmium concentration the more iESTs were observed $(4.3 \%$ of all ESTs sequenced from CDC library $\left(100 \mu \mathrm{M} \mathrm{CdCl}_{2}\right)$ corresponded to iESTs while in CDM library $\left(50 \mu \mathrm{M} \mathrm{CdCl}_{2}\right)$ this percentage was only $2.7 \%$. Besides cadmium libraries, one cDNA library was constructed from cells submitted to heat shock in a moderate temperature $\left(38^{\circ} \mathrm{C}\right)$ and even in this library we detected an enrichment of iESTs (1.1\%). This observation is quite interesting since inhibition of splicing by thermal stress was already observed in $B$. emersonii, but only at lethal temperatures $\left(42^{\circ} \mathrm{C}\right)$ [13]. These data indicate that intron splicing is affected in $B$. emersonii cells maintained at $38^{\circ} \mathrm{C}$, but the effect observed in the splicing process is not so severe as the one detected in cells exposed to heat shock at $42^{\circ} \mathrm{C}$ [13] or cadmium treatment.

Sequencing of iESTs reported here provides considerable new information about $B$. emersonii intron structure and sequence, as only nine genes with their introns sequenced 
A

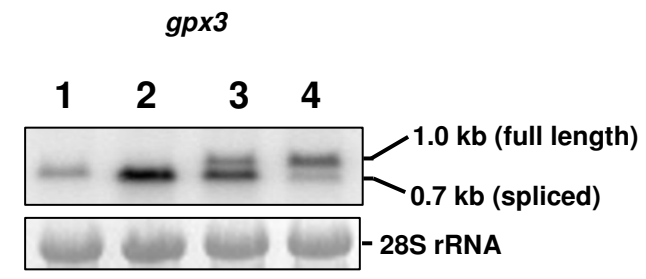

B

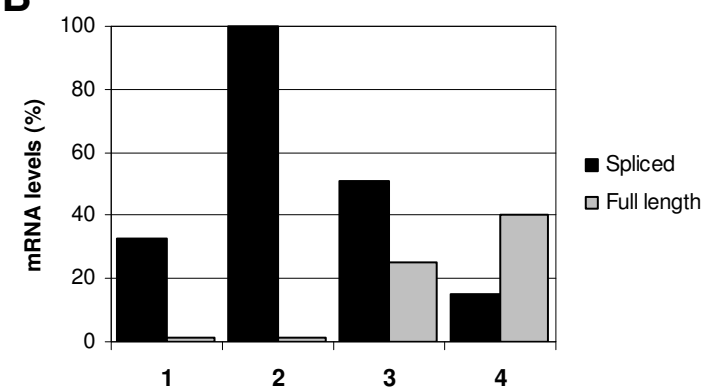

Figure 5

Analysis of gpx3 mRNA in cells exposed to heat shock and cadmium stress. A-Northern blot assay was performed using total RNA extracted from $B$. emersonii cells submitted to different cadmium concentrations or to heat shock. RNA extracted from cells 60 min after sporulation induction (lane I). RNA extracted from cells submitted to heat shock $\left(38^{\circ} \mathrm{C}\right)$ from 30 to $60 \mathrm{~min}$ (lane 2) after induction of sporulation. RNA extracted from cells $60 \mathrm{~min}$ after sporulation induction, incubated with $50 \mu \mathrm{M}$ or $100 \mu \mathrm{M} \mathrm{CdCl}_{2}$ from 30 to 60 min (lanes 3 and 4, respectively) after sporulation induction. As a control of RNA levels, the 28S rRNA was shown. B -- Relative transcript levels of gpx3 mRNA determined by densitometry scanning of the autoradiogram shown in A. The figure legend (I, 2, 3 and 4$)$ is the same depicted above.

and deposited in GenBank database have been previously described in B. emersonii $[13,26-33]$. Thus, the present study contributes significantly to the knowledge about gene organization in this fungus.

Among the 85 genes whose corresponding mRNAs retained introns in the stress cDNA libraries, a total of $22 \%$ of them presented two or three introns. Fungal genes are commonly interrupted by few and small introns in comparison with metazoan genes. Intron density ranges from five to six per gene in basidiomycetes as Cryptococcus neoformans [46], from one to two per gene in recently sequenced ascomycetes as Neurospora crassa and Magnaporthe grisea $[47,48]$, and less than 300 introns present in the entire S. cerevisiae genome [49], while human genes are interrupted in average by eight introns [50]. Thus, considering the number of introns reported here, B. emersonii's gene structure appears to be more similar to that observed in ascomycetes. Further evidence suggesting that
B. emersonii gene structure is more similar to ascomycetes is the average intron length observed in this aquatic fungus. We detected introns ranging from 55 to 333 nucleotides, an intron length more similar to that observed in the ascomycete species [49-51]. However, it is relevant to notice that even fungi belonging to the same class present different gene structures, as the case of Ustilago maydis, a basidiomycete that possesses an average number of introns per gene smaller than one $[52,53]$.

To further characterize the intron structure of B. emersonii genes, we have identified the splicing junctions present in the introns sequenced from iESTs. We observed that most of the introns showed the canonical splicing sites and the consensus branch site sequence similar to those detected in introns from genes previously characterized in B. emersonii. These observations suggest that inhibition of splicing by stress in $B$. emersonii is probably a random process opposite to a selective inhibition of some specific premRNAs based on different intron-recognition sequences.

The fact that $B$. emersonii possesses proteins involved in pre-mRNA processing containing zinc-related domains indicates that one possible mechanism by which cadmium inhibits splicing in this fungus could be the displacement of zinc ions from these proteins. This hypothesis is consistent with the fact that we did not observe a global repression in the transcription of genes encoding spliceosome proteins under these stress conditions. Additionally, the $h s p 70-1$ gene intron was not found to be retained when $B$. emersonii cells were treated with hydrogen peroxide. These data suggest that splicing blockage is not due to an indirect effect of oxidative stress caused by cadmium. Furthermore, Shomron and collaborators [54] demonstrated that zinc is an essential factor for the second step of the splicing reaction, suggesting that putative zinc-dependent metalloproteins are required for this step of RNA splicing process. Interestingly, a recent report demonstrated that cadmium, a metal that presents many chemical similarities to zinc, in low quantities can restore in vitro mRNA splicing inhibited by zinc-depletion [55]. These results indicated that cadmium could effectively substitute zinc in metalloproteins, including those present in the spliceosome machinery [55]. Nevertheless, at higher concentrations the authors observed that cadmium caused the opposite effect, inhibiting splicing in vitro [55]. In fact, cadmium should exert a direct effect in the spliceosome complex, by displacing zinc, since at high concentrations of zinc, no splicing inhibition was observed, a higher cadmium concentration treatment being necessary to detect intron retention [55].

The mechanism of zinc displacement is not applicable to splicing inhibition by thermal stress. In this case, most probably inhibition is due to the unfolding of spliceo- 
some proteins as a consequence of high temperature. Consistent with this hypothesis, it was observed that heat shock proteins (HSPs) are involved in the protection of the spliceosome complex at higher temperatures [56]. Yeast cells made thermotolerant by preincubation at $37^{\circ} \mathrm{C}$ completely protect spliceosome snRNPs complexes from disruption when subsequently exposed to a more severe stress at $42^{\circ} \mathrm{C}[56]$.

Interestingly, we also observed that in B. emersonii cells made thermotolerant by pretreatment at $38^{\circ} \mathrm{C}$ and later exposed to cadmium, mRNA processing is less affected than in cells not previously treated. One possible explanation of this thermoprotection effect in mRNA processing machinery is that during heat shock cells could be inducing the expression of proteins that are important to the response to temperature stress but that are also important in the response to cadmium treatment. In fact, during the response to heat shock, $B$. emersonii cells induce not only the expression of heat shock protein genes but also genes encoding several antioxidant proteins [19], which could be exerting a protective effect in cells subsequently exposed to cadmium. Indeed, we observed here that $B$. emersonii gpx3 gene, which encodes a Glutathione peroxidase, is highly induced in response to both heat shock and cadmium treatment.

Another possible explanation for splicing inhibition by cadmium and heat shock could be that under these conditions introns are retained in some genes just because they are alternatively spliced. However, this hypothesis does not hold as only $30 \%$ of the iESTs maintain their reading frames, and at least for the hsp70-1 gene the protein originated from this putative alternative splicing was not detected in western blots [13], indicating that the unspliced mRNA is not efficiently translated. It is important to notice that another process that could be affected by cadmium treatment resulting in intron retention is the machinery of nonsense-mediated decay, since this complex is responsible for the degradation of unspliced mRNAs in the cell [57].

In yeast, transcript-specific changes in splicing were observed in response to environmental stresses. For instance, it was shown that in response to amino acid starvation splicing of most ribosomal protein-encoding genes was inhibited, splicing being an important opportunity for regulation of gene expression in response to stress [45]. This kind of post-transcriptional regulation does not seem to be the case during splicing inhibition by heat and cadmium stresses in B. emersonii, as we did not observe a pattern among the genes whose pre-mRNA splicing was inhibited, indicating that there was no preference for transcripts that are involved in specific biological processes.
To confirm the inhibitory effect of cadmium in the spliceosome machinery we performed S1 nuclease protection and Northern blot assays to analyze the splicing of two different mRNAs ( $h s p 70-1$ and $g p x 3$ ) under this stress condition. Inhibition of pre-mRNA splicing of both genes was observed when $B$. emersonii cells were submitted to cadmium, validating our sequencing data. Although intron retention could be a $B$. emersonii response to stress treatment, it is still unclear to us what kind of benefits this response could bring to the cell. In fact, the results do not seem to indicate that intron retention might be a regulatory mechanism under stress conditions. On the contrary, it is most probable that this event occurs randomly, being the most abundant mRNAs more affected, as those corresponding to genes induced in response to stresses.

\section{Conclusion}

This work demonstrates that environmental stresses, mainly cadmium exposure, inhibit splicing in B. emersonii. The cellular effects of cadmium, which lead to its toxicity, have been investigated in recent years. These effects include generation of oxidative stress, lipid peroxidation, mutagenesis and others. However, until now no description of an effect of cadmium on the spliceosome machinery was reported. Thus, this study contributes to the elucidation of a new mechanism promoting cadmium toxicity to the cells.

\section{Authors' contributions}

RCG carried out the construction and analysis of stress cDNA libraries, bioinformatics analysis, Northern blot experiments and drafted the manuscript. RMPS carried out S1 protection assays. SLG participated in study design and coordination and helped to draft the manuscript. All authors read and approved the final manuscript.

\section{Additional material}

\section{Additional file 1}

B. emersonii genes corresponding to iESTs sequenced from stress cDNA libraries. The table shows the ESTs sequenced that retained introns.

Click here for file

[http://www.biomedcentral.com/content/supplementary/14712180-9-231-S1.pdf]

\section{Additional file 2}

Genes encoding spliceosome proteins in $\mathrm{B}$. emersonii, annotated in GO category "mRNA processing". The table shows ESTs that participate in $m R N A$ processing in $\mathrm{B}$. emersonii.

Click here for file

[http://www.biomedcentral.com/content/supplementary/14712180-9-231-S2.pdf] 


\section{Additional file 3}

$S 1$ protection assays of hsp70 $m R N A$ in different cadmium concentrations. The figure shows Sl protection assays of hsp70 mRNA using total RNA extracted from B. emersonii cells submitted to different cadmium concentrations

Click here for file

[http://www.biomedcentral.com/content/supplementary/14712180-9-231-S3.pdf]

\section{Acknowledgements}

This work was supported by a grant from Fundação de Amparo à Pesquisa do Estado de São Paulo (FAPESP). SLG was partially supported by Conselho Nacional de Desenvolvimento Científico e Tecnológico (CNPq). RCG and RMPS were fellows of FAPESP.

\section{References}

I. Bond U: Stressed out! Effects of environmental stress on mRNA metabolism. FEMS Yeast Res 2006, 6:160-70.

2. Jurica MS, Moore MJ: Pre-mRNA splicing: awash in a sea of proteins. Mol Cell 2003, I 2:5-14.

3. Nilsen TW: The spliceosome: the most complex macromolecular machine in the cell? Bioessays 2003, 25:1 I47-9.

4. Konarska MM: Recognition of the 5' splice site by the spliceosome. Acta Biochim Pol 1998, 45:869-8I.

5. Nilsen TW: The spliceosome: no assembly required? Mol Cell 2002, 9:8-9.

6. Brow DA: Allosteric cascade of spliceosome activation. Annu Rev Genet 2002, 36:333-60.

7. Heckman DS, Geiser DM, Eidell BR, Stauffer RL, Kardos NL, Hedges $\mathrm{SB}$ : Molecular evidence for the early colonization of land by fungi and plants. Science 200I, 293: I I 29-I I 33.

8. Auwera G Van der, Wachter RD: Large-subunit rRNA sequence of the chytridiomycete Blastocladiella emersonii, and implications for the evolution of zoosporic fungi. J Mol Evol 1996, 43:476-483.

9. Lovett JS: Growth and differentiation of the water mold Blastocladiella emersonii: cytodifferentiation and the role of ribonucleic acid and protein synthesis. Bacteriol Rev 1975, 39:345-404.

10. Yost H], Lindquist S: Heat shock proteins affect RNA processing during the heat shock response of Saccharomyces cerevisiae. Mol Cell Biol 199I, I I:1062-8.

II. Yost HJ, Lindquist S: RNA splicing is interrupted by heat shock and is rescued by heat shock protein synthesis. Cell 1986, 25: $185-93$.

12. Bond U: Heat shock but not other stress inducers leads to the disruption of a sub-set of snRNPs and inhibition of in vitro splicing in HeLa cells. EMBO J 1988, 7:3509- I8.

13. Stefani RM, Gomes SL: A unique intron-containing hsp70 gene induced by heat shock and during sporulation in the aquatic fungus Blastocladiella emersonii. Gene 1995, 152:19-26.

14. Bond $U$, James TC: Dynamic changes in small nuclear ribonucleoproteins of heat-stressed and thermotolerant HeLa cells. Int J Biochem Cell Biol 2000, 32:643-56.

15. Silva AM, Maia JCC, Juliani MH: Changes in the pattern of protein synthesis during zoospore germination in Blastocladiella emersonii. J Bacteriol 1987, 169:2069-2078.

16. Stohs SJ, Bagchi D: Oxidative mechanisms in the toxicity of metal ions. Free Radic Biol Med 1995, 18:321-36.

17. Schützendübel A, Polle A: Plant responses to abiotic stresses: heavy metal-induced oxidative stress and protection by mycorrhization. J Exp Bot 2002, 53:1351-65.

18. Faller P, Kienzler K, Krieger-Liszkay A: Mechanism of $\mathbf{C d}^{2+}$ toxicity: $\mathrm{Cd}^{2+}$ inhibits photoactivation of Photosystem II by competitive binding to the essential $\mathrm{Ca}^{2+}$ site. Biochim Biophys Acta 2005, 7:158-64.

19. Georg RC, Gomes SL: Transcriptome analysis in the aquatic fungus Blastocladiella emersonii in response to heat shock and cadmium. Eukaryot Cell 2007, 6:1053-1062.
20. Huang $X$, Madan A: CAP3: A DNA sequence assembly program. Genome Res 1999, 9:868-77.

21. Altschul SF, Madden TL, Schaffer AA, Zhang J, Zhang Z, Miller W, Lipman DJ: Gapped BLAST and PSI-BLAST: a new generation of protein database search programs. Nucleic Acids Res 1997, 25:3389-3402.

22. Ribichich KF, Salem-Izacc SM, Georg RC, Vêncio RZN, Navarro LD Gomes SL: Gene discovery and expression profile analysis through sequencing of expressed sequence tags from different developmental stages of the chytridiomycete Blastocladiella emersonii. Eukaryot Cell 2005, 4:455-464.

23. Blastocladiella emersonii EST database [http://blasto.iq.usp.br]

24. Georg RC, Gomes SL: Comparative expression analysis of members of the Hsp70 family in the Chytridiomycete Blastocladiella emersonii. Gene 2007, 386:24-34.

25. Green MR: Biochemical mechanisms of constitutive and regulated pre-mRNA splicing. Annu Rev Cell Biol I991, 7:559-99.

26. Marques MV, Gomes SL: Cloning and structural analysis of the gene for the regulatory subunit of CAMP-dependent protein kinase in Blastocladiella emersonii. I Biol Chem 1992, 267: $17201-7$.

27. Oliveira JC, Borges AC, Marques MV, Gomes SL: Cloning and characterization of the gene for the catalytic subunit of CAMP. dependent protein kinase in the aquatic fungus Blastocladiella emersonii. Eur J Biochem 1994, 219:555-62.

28. Rocha CR, Gomes SL: Isolation, characterization, and expression of the gene encoding the beta subunit of the mitochondrial processing peptidase from Blastocladiella emersonii. J Bacteriol 1998, 180:3967-72.

29. Souza FS, Gomes SL: A P-type ATPase from the aquatic fungus Blastocladiella emersonii similar to animal $\mathrm{Na}, \mathrm{K}-\mathrm{ATPases}$. Biochim Biophys Acta 1998, 2:183-7.

30. Rocha CR, Gomes SL: Characterization and submitochondrial localization of the alpha subunit of the mitochondrial processing peptidase from the aquatic fungus Blastocladiella emersonii. J Bacteriol 1999, 181:4257-65.

31. Simão RC, Gomes SL: Structure, expression, and functional analysis of the gene coding for calmodulin in the chytridiomycete Blastocladiella emersonii. J Bacteriol 200I, I83:2280-8.

32. Fietto LG, Pugliese L, Gomes SL: Characterization and expression of two genes encoding isoforms of a putative $\mathrm{Na}, \mathrm{K}$ ATPase in the chytridiomycete Blastocladiella emersonii. Biochim Biophys Acta 2002, 7:59-69.

33. Pugliese L, Georg RC, Fietto LG, Gomes SL: Expression of genes encoding cytosolic and endoplasmic reticulum HSP90 proteins in the aquatic fungus Blastocladiella emersonii. Gene 2008, 4 II:59-68.

34. Maier T, Yu C, Küllertz G, Clemens S: Localization and functional characterization of metal-binding sites in phytochelatin synthases. Planta 2003, 2 1 8:300-8.

35. Rollin-Genetet $F$, Berthomieu $C$, Davin $A H$, Quéméneur $E$ : Escherichia coli thioredoxin inhibition by cadmium: two mutually exclusive binding sites involving Cys32 and Asp26. Eur J Biochem 2004, 27 I:1299-309.

36. PFAM protein database [http://pfam.sanger.ac.uk]

37. Nesic $D$, Krämer $A$ : Domains in human splicing factors SF3a60 and SF3a66 required for binding to SF 3 a 120 , assembly of the I7S U2 snRNP, and prespliceosome formation. Mol Cell Biol 200I, $21: 6406-17$.

38. Morrison AA, Viney RL, Ladomery MR: The post-transcriptional roles of WTI, a multifunctional zinc-finger protein. Biochim Biophys Acta 2008, 1785:55-62.

39. Mangs AH, Morris BJ: ZRANB2: structural and functional insights into a novel splicing protein. Int / Biochem Cell Biol 2008, 40:2353-7.

40. McGrail JC, Krause A, O'Keefe RT: The RNA binding protein Cwc2 interacts directly with the U6 snRNA to link the nineteen complex to the spliceosome during pre-mRNA splicing. Nucleic Acids Res 2009, 283:2644-53.

4I. Gasch AP, Spellman PT, Kao CM, Carmel-Harel O, Eisen MB, Storz $G$, Botstein D, Brown PO: Genomic expression programs in the response of yeast cells to environmental changes. Mol Biol Cell 2000, I I:424I-57.

42. Causton HC, Ren B, Koh SS, Harbison CT, Kanin E, Jennings EG, Lee TI, True HL, Lander ES, Young RA: Remodeling of yeast genome 
expression in response to environmental changes. Mol Biol Cell 200I, I 2:323-37.

43. Vido K, Spector D, Lagniel G, Lopez S, Toledano MB, Labarre J: A proteome analysis of the cadmium response in Saccharomyces cerevisiae. J Biol Chem 2001, I 6:8469-74.

44. Fauchon M, Lagniel G, Aude JC, Lombardia L, Soularue P, Petat C, Marguerie G, Sentenac A, Werner M, Labarre J: Sulfur sparing in the yeast proteome in response to sulfur demand. Mol Cell 2002, 9:7।3-23.

45. Pleiss JA, Whitworth GB, Bergkessel M, Guthrie C: Rapid, transcript-specific changes in splicing in response to environmental stress. Mol Cell 2007, 21 ;27(6):928-37.

46. Loftus BJ, Fung E, Roncaglia P, Rowley D, Amedeo P, Bruno D, et al.: The genome of the basidiomycetous yeast and human pathogen Cryptococcus neoformans. Science 2005, 25: I32I-4.

47. Galagan JE, Calvo SE, Borkovich KA, Selker EU, Read ND, Jaffe D, et al:: The genome sequence of the filamentous fungus $\mathrm{Neu}$ rospora crassa. Nature 2003, 422:859-68.

48. Dean RA, Talbot NJ, Ebbole DJ, Farman ML, Mitchell TK, et al.: The genome sequence of the rice blast fungus Magnaporthe grisea. Nature 2005, 434:980-6.

49. Goffeau A, Barrell BG, Bussey H, Davis RW, Dujon B, Feldmann H, et al.: Life with $\mathbf{6 0 0 0}$ genes. Science 2005, 274:563-7.

50. Lander ES, Linton LM, Birren B, Nusbaum C, Zody MC, Baldwin J, et al.: Initial sequencing and analysis of the human genome. Nature 200I, 409:860-92I.

5I. Kupfer DM, Drabenstot SD, Buchanan KL, Lai H, Zhu H, Dyer DW, Roe BA, Murphy JW: Introns and splicing elements of five diverse fungi. Eukaryot Cell 2004, 3:1088-100.

52. Ho EC, Cahill MJ, Saville BJ: Gene discovery and transcript analyses in the corn smut pathogen Ustilago maydis: expressed sequence tag and genome sequence comparison. BMC Genomics 2007, 24(8):334.

53. Kämper J, Kahmann R, Bölker M, Ma LJ, Brefort T, Saville BJ, Banuett F, Kronstad JW, Gold SE, Müller O, Perlin MH, Wösten HA, de Vries R, Ruiz-Herrera J, Reynaga-Peña CG, Snetselaar K, McCann M, PérezMartín J, Feldbrügge M, Basse CW, Steinberg G, Ibeas JI, Holloman W, Guzman P, Farman M, Stajich JE, Sentandreu R, González-Prieto JM, Kennell JC, Molina L, Schirawski J, Mendoza-Mendoza A, Greilinger D, Münch K, Rössel N, Scherer M, Vranes M, Ladendorf O, Vincon V, Fuchs U, Sandrock B, Meng S, Ho EC, Cahill MJ, Boyce KJ, Klose J, Klosterman S], Deelstra HJ, Ortiz-Castellanos L, Li W, SanchezAlonso P, Schreier PH, Häuser-Hahn I, Vaupel M, Koopmann E, Friedrich G, Voss H, Schlüter T, Margolis J, Platt D, Swimmer C, Gnirke A, Chen F, Vysotskaia V, Mannhaupt G, Güldener U, Münsterkötter M, Haase D, Oesterheld M, Mewes HW, Mauceli EW, DeCaprio D, Wade CM, Butler J, Young S, Jaffe DB, Calvo S, Nusbaum C, Galagan J, Birren BW: Insights from the genome of the biotrophic fungal plant pathogen Ustilago maydis. Nature 2006, 444:97-I0I.

54. Shomron N, Malca H, Vig I, Ast G: Reversible inhibition of the second step of splicing suggests a possible role of zinc in the second step of splicing. Nucleic Acids Res 2002, 30:4I 27-37.

55. Lee MJ, Ayaki H, Goji J, Kitamura K, Nishio $\mathrm{H}$ : Cadmium restores in vitro splicing activity inhibited by zinc-depletion. Arch Toxicol 2006, 80:638-43.

56. Bracken AP, Bond U: Reassembly and protection of small nuclear ribonucleoprotein particles by heat shock proteins in yeast cells. RNA 1999, 5:1586-96.

57. Sayani S, Janis M, Lee CY, Toesca I, Chanfreau GF: Widespread impact of nonsense-mediated mRNA decay on the yeast intronome. Mol Cell 2008, 8:360-70.
Publish with Bio Med Central and every scientist can read your work free of charge

"BioMed Central will be the most significant development for disseminating the results of biomedical research in our lifetime. "

Sir Paul Nurse, Cancer Research UK

Your research papers will be:

- available free of charge to the entire biomedical community

- peer reviewed and published immediately upon acceptance

- cited in PubMed and archived on PubMed Central

- yours - you keep the copyright
BioMedcentral 